\title{
Renaming States-A Case Study: Changing the Name of the Hungarian State in 2011. Its Background, Reasons, and Aftermath
}

\section{Peter Takács ${ }^{1}$ (D)}

Published online: 17 March 2020

(c) The Author(s) 2020

\begin{abstract}
A provision of the Hungarian constitution, adopted in 2011, has renamed the state. The name changed from the Republic of Hungary to Hungary, while the form of the state has remained "republic". The purpose of this study is to explore the meaning, significance, and several consequences of this provision. The analysis consists of three main parts. The first one gives a general overview of the functions of the names of states. It claims that not only names but also changing or modifying names of states - taking place either by name-giving or by shaping convention-can serve certain functions. The second part focuses on the historical and constitutional details of renaming the Hungarian state, and summarizes the legal context that provided the framework for the 2011 renaming. The third part outlines the arguments for the change, takes a look at the official justification and actual reasons, and reveals some of the consequences of the name change in the past decade. The main contention of the paper is that the renaming of the Hungarian state that took place in 2011 lacked any overt and reasonable justification, and is best explained as an expression of antirepublican sentiment, which indicated, and partly paved the way for the transition into a kind of an authoritarian regime. Finally, the study raises a possible interpretation of the renaming of the Hungarian state in 2011, the point of which is that it adumbrated many later changes in public law and political systems.
\end{abstract}

Keywords Names of the Hungarian state during the twentieth century - The role of "republic" as a denomination of state in the context of Hungarian history - Semantic background and justification for renaming the Hungarian state in 2011 · Functions of country names and state titles - Country names and the collective identity of larger communities · Fundamental Law of Hungary

Peter Takács

takacs.peter@outlook.hu; takacs.peter@sze.hu

1 Széchenyi István University, Győr, Hungary 
The name of the Hungarian state changed several years ago. Between 1989 and 2011 the title of the state was the Republic of Hungary which-pursuant to one of the provisions of the 2011 Fundamental Law of Hungary - was replaced by Hungary as of 1 January 2012, notwithstanding the form of the state has remained a republic. Why such a change happened, how did it take place and what consequences has it had? The past few years offer a sufficient perspective for answering these questions.

\section{The General Context of Renaming States}

Before analyzing the renaming a particular state, it seems appropriate to review two general questions that may play a significant role in interpreting such changes: what are the functions of the names of states in internal and external communication, and what is the social and political significance of states' name-giving and name change.

\subsection{Functions of Country Names and State Titles}

Similar to personal names, country names and state titles have several functions in communication. ${ }^{1}$ In the case of the state titles, these are social and political by their character.

Just like in the case of every unique being, the names of states ensure the possibility of denoting and identifying them uniquely. Country names and names of states $^{2}$ enable the invocation of individual states in different discourses as well as the relevant communication regarding to and on those states, namely to saying something about them. Moreover, under specific circumstances, the name displays the state, thus presents and "re-presents" the unique and existing states which may occur symbolically and expressively. All the more, in the case of so-called "picturesque" names, it can even evolve through some characterization. In the latter case, we can also talk about some degree of a description of the country and state in question, even if it consists of only one or two words. Instead of the objective enumeration of a phenomenon, the description sometimes stands for the formulation of the desirable

\footnotetext{
1 Linguistics and communication theories discuss the functions of names in the context of proper names in detail—for the relevant scholarship that could be used for this purpose see [10, 19, 20, 42]—, general theories, however, have not been adapted yet to the names of states. One of the widely accepted general theories on the communicative functions of linguistic phenomena was developed by Roman Osipovich Jakobson who concentrated not only to the relationship of sender or recipient but of sender and recipient [see 24: 81-122]. According to my knowledge, there is no linguistic analysis in the literature that applies general literature, mentioned above, to the special issue of the function of state names.

${ }^{2}$ Every state has two names: country name, which is the short-form of the name of state, and the longform of the name of state (in British English it is called state titles), which, in certain case, is constitutional name. They are interchangeable within certain limits. Country names are quite often used to denominate states, the long-form of a particular state, however, does not necessarily refer to an actually existing country, especially in the case of politically divided communities.
} 
features of a phenomenon, or masks the undesirable traits, for instance when an authoritarian state or dictatorship is called "people's democracy". In other words, state titles - unlike personal names - may have functions that facilitate the acceptance of the political system of the state (legitimization). Since the state is perceived as a political community, the name may contribute to the confirmation and fortification of the identity of this community or to the re-creation it (identity creation). ${ }^{3}$ Just like in the case of all names, the most basic function of state titles is to contribute to the guarding of a particular phenomenon's identity (identity protection). One of the tools of identity protection includes the case when the name reminds the members of a particular community of its history. Sometimes this protection could take even "magical" form. This is the case when a substitute rather than "actual" name is used, to prevent the identity from being "stolen" (rather than forgotten), as e.g. in the case of "Rome". In such cases, however, the substitute sooner or later may blur the original or actual name, if there was any. ${ }^{4}$ Names may also have a reminding function or nature, which can be called a function of commemoration as well.

In short, names of states may thus perform the following main functions: (a) denotation, (b) identification, (c) description, (d) invocation, (e) supply or withdrawal of information (communication in the narrow sense), (f) representation, (g) remembrance and reminder (commemoration), (h) legitimization, and (1) identity creation or identity protection.

It is not necessary for a name to fulfill all these functions at once or continuously; however, it needs to perform at least one or some of them. Regarding these functions, the following three general statements can be made:

(1) It is possible that the same name fulfilling one of the functions in a certain communicative context may not work or may be dysfunctional in another one. Moreover, individual functions may even counteract in certain situations.

(2) Some functions may be interpreted negatively. For instance, it is possible that a particular mode of name fails to communicate something and seeks to withhold or mask (disguise) something. This may also be part of the communicative function, of course negatively.

(3) Certain functions only operate within the linguistic community of those speaking a particular language.

The detailed elaboration of these claims I begin with the latter which becomes evident in the case of "picturesque" or "talkative" names. A well-known example

\footnotetext{
${ }^{3}$ On the so-called identity-creating functions of geographical "place names", in general, see [17: 105106]. For country names are "place names", some of the findings of this paper can be adapted to the names of states as well.

${ }^{4}$ It is known that by the eighteenth century the name of the so-called German-Roman empire-which was originally called Imperium Romanum, after 1157 Sacrum Imperium in the sense of being "consecrated", finally after 1512 Sacrum Imperium Romanum Nationis Germanica-has become deceptive, as Voltaire's sarcastic remark indicated in 1756. According to Voltaire "This agglomeration which was called and which still calls itself the Holy Roman Empire was in neither holy, nor Roman, nor an empire" (Ce corps qui s'appelait et qui s'appelle encore le saint empire romain n'était en aucune manière ni saint, ni romain, ni empire). See [41: 416].
} 
of the descriptive function of names is provided by the name of Montenegro. For locals, its name is Црна Гора (Crna Gora), which was introduced in Slavic languages by Italian in Romanic translation (monte: mountain, negro: black); thus, this country name means "black mountain" or "land of the black mountain" [29: 3]. Just like proper names, state names can have a reminding function by which they contribute to the forging or protection of community identity in a wider political community. An interesting example is provided by Venezuela whose long name (Bolivarian Republic of Venezuela) refers to the late leader of the South American independence movement, president and subsequent dictator of Venezuela, Simón Bolívar. ${ }^{5}$

The fact that particular functions may also counteract does not, in itself, render names useless. The identification function of names may be operational even if their descriptive nature is questionable, namely if the content of the state name does not correspond to facts. Those who think that names cannot state the opposite of obvious facts often will be disappointed: states move within relatively wide limits in this regard. Certainly, republics are usually not called monarchies and vice versa; it is, however, very much possible that beyond the denomination of republic there is some form of dictatorship - there are many instructive examples of this from the Italian city-states of early modern-times to today's Eastern European states.

There are various tools for processing the discrepancy between sense and reference in the context of state names, as well. It includes, among others, the frequent use of abbreviations. This is particularly characteristic for politicized or so-called imperial languages: in the times of the Soviet Union, the long forms of state names (state titles) of Soviet republics were rarely or never used in conversations. Instead, country names and shortened forms of state names were employed (e.g., in the case of Ukraine such an example was the Ukrainian SSR). It is a well-known fact that abbreviations also had a distracting function: for instance, the former German Democratic Republic was often called GDR since this usage did not express, and thus rendered it redundant to question, whether this state was really "democratic" or not. ${ }^{6}$

The descriptive function is left in the background in those cases in which the determinants of the long form of state name do not simply indicate the state form in the name but attempt to legitimize the political and public law system denominating the state. In this case, they do not only indicate but also classify the form of state, for instance by calling the state "democratic", "socialist", "Arab", "Islamic" republic or eventually "people's republic". In other words, they supplement the general communicative function by a political one. The aim of the aforementioned classifications is to represent, reinforce and endorse the dominant ideology of a particular state at the level of the state form (form of government), thus contributing to the legitimization of the political order with the state name itself. There are states-in the case of which we may even doubt the accuracy of one attributes-that duplicate

\footnotetext{
5 The long form of state name of Venezuela was determined by the 1999 Constitution that replaced the 1961 Constitution and was adopted by a referendum at the proposal of Hugo Chávez [7].

${ }^{6}$ For this example and its interpretation, see [28: 94] (on the function of abbreviations). For the political content of the abbreviation $G D R$, see [18: 93-107].
} 
these attributes and call themselves, for instance, "democratic socialist republic" or "democratic people's republic".

A further function of state names is contributing to the identity protection of a community as well as to the creation of a new identity in those cases in which the nature of the state changes. Not only names but also changing or modifying names of states can serve certain functions. These are mostly similar to some of the main functions of names of state, but there are also differences. The basic functions of changing names are (a) the creation of a new identity for the community, (b) legitimization a new political order of the state to be created, (c) the drawing a spectacular dividing line between the new and the old political regimes, (d) remembering the past, remember it otherwise or just missing something out of it, and so on. These functions will be spelled out and demonstrated in relation to changing the name of the state, determining, first, its two ways (name-giving and name change), second, the special functions that the change of state name fulfills in them, adding a few examples, too.

\subsection{Giving Names for the Countries and Changing Names of States}

Similar to human beings, the states acquire their names by someone's giving them one. This can evolve in two main ways: by convention or by name-giving.

Denomination of states by linguistic convention concerns states whose names are based on peoples' and nations' names. Many state names evolved-with the transmission of country names - from the name of (one of) the people(s) living on the territory of the state, or directly corresponds with the country name. ${ }^{7}$ Although such denominations are natural, on the basis of European history, they may lead to uncertainty for two reasons. First, peoples themselves and their linguistic habits constantly change. Second, individual countries may, for a shorter or longer period of time, fall under the "control" of different states. (This is so obvious that it suffices here to refer shortly to the troubled relationship of "Polish people", the "land of the Poles" and the "Polish state" during the nineteenth century.) Furthermore, the convention may sometimes be reversed in direction: it is not the state name that evolves from the name of the people living on its territory but the people or nation is named, after some time, based on the name of the state. At least this appears to be the case for the "first new nation" [c.f. 27], the American, and the United States of America. This reverse process could be illustrated with European examples as well.

The second way of the denomination of states is name-giving. Name giving has the following meaning: consciously and by a single act we assign a linguistic sense to something and identify it as well as have this identification approved in a narrower or wider community. Certainly, in a philosophical sense, name-giving means much more than that. G. W. F. Hegel recognized that possession-apart from the "physical seizure" and "shaping"—of something takes place with "denotation". This

\footnotetext{
${ }^{7}$ For these aspects of state names, basically those of country names see [1: 1348-1356].
} 
latter includes name-giving, among others. However, as Hegel argued, name-giving amounts not only to possession but also to creation. This idea occupied him from his late youth onwards; as he noted in the Jena Practical Philosophy, the entity of the cognitive acquisition of reality "gives a name to a thing" through its meaning, "and expresses this names as the existence of the subject, (...) [thus] presupposing the inner as existent". Therefore, through name-giving, the renowned Hegelian Spirit (German: Geist) creates, acquires as well as takes possession of nature [15: 175]. ${ }^{8}$

This idea of Hegel is, from certain perspectives, a reiteration of a Christian notion on names and name-giving, stemming from Jewish ideas, with the utilization of medieval debates on universals. ${ }^{9}$ This question cannot be examined here in detail; but it needs to be noted that the interpretation of words and names-beyond philosophical problems - played a significant role in this dispute since, for Christians, the meaning of personal names in the Holy Scripture does not allow for its reconciliation with the view of nominalists. For Christian thinkers, name-giving and name changing constitute the beginning of a new personality as they believe that names quasi "unfold" the essence and designation of a person. ${ }^{10}$

A significant interrelation is provided by the fact that he who gives a name, gives something that he does not possess - at least at first glance. "And what happens when we give a name? What do we give then?"- asks Jacques Derrida. In order not to leave his readers in doubt, he replies instantly: in such cases, "we do not offer one thing", "we do not offer anything"; however, there occurs something that amounts to giving something that we do not possess-as the Good of Plotinus [12: 70]. A more accurate analysis of the situation of name-giving easily shows that this idea of Derrida conceived at a higher level of abstraction cannot be directly applied for the denomination of persons, things and, especially, states. It is true that he who gives a name to a state gives something that he does not possess, but he does possess something that is indispensable for the matching of sense and reference (name and person, name and state, etc.), thus something essential for name-giving. Namely, he has the right or power to influence language usage. Therefore, with respect to namegiving, "creation" and "production" amount to influencing and shaping human relations - and in certain cases, to their transformation as regards the usage of names. That is why name-giving, as well as name change, is an emphatically political act that takes place in a legal framework.

Functions of renaming states can be ascertained by clarifying the main historical types of renaming, either by the evolution of convention or by name-giving. Based

\footnotetext{
${ }^{8}$ For the concept of possession, see [16: 60-63: par. 54-58]. For Hegel's theory on names, see [4: 74-77].

${ }^{9}$ In the Bible, where "the man gave names to all the livestock, the birds in the sky and all the wild animals" (Gen, 2:20), name giving, creation and possession are also closely related: "Do not fear-said the Lord-, for I have redeemed you; I have summoned you by name; you are mine" (Isaiah, 43:1). This has appeared almost one-in-one in Hegel's theory, expressed in philosophical terms. On Jewish ideas on names see Exodus 3:13-22.

${ }^{10}$ C.f. Gen, 27:36, and Isaiah, 7:14. Worth a note here that when Jesus called Simon Cephas [Peter] in the text of the so-called promise to build the Church, he knew that this name is not understood by the Aramaic-speaking Jews; therefore, he explicitly referred to its symbolic meaning ("You are Peter, and on this rock I will build my Church..."), thus revealing the "real" or "actual" meaning" of the name; c.f. Mark, 3:16-19 and Matt, 16:18-21. For a possible philosophical background of these views see [31: 383a-385e].
} 
on the experience of the twentieth century the following three main types of renaming states can be distinguished here.

(1) Name change reflecting a complete change in the social, economic and political nature of the state. A special subtype of this case is a historically rapid and comprehensive change in the social or economic "content" of the state called modernization.

(2) Name change concerning the disintegration of the great empires, when their subdivisions as successor states are renamed. Another variant of this type is when colonies become independent states.

(3) Name change connected to significant changes in the political content of the state. One variant of it is the change of the form of state (e.g. from monarchy to republic, or vice versa). We can classify here the permanent planned change the methods or institutions of political rule, and in the direction of the administration, without changing the form of state.

The following few examples illustrate these main types. The best-known example of the first type is the Russian state, whose name has changed with revolutionary changes. In 1917 the Russian Empire (Российская Империя), a monarchy, became first, Russian Republic (Российская республика; September 1917), then, after 6 weeks, Soviet Russia or Russian Socialist Soviet Republic (Российская социалисти́ческая сове́тская респу́блика; November 1917). This latter was mutated into Soviet Union or Union of Soviet Socialist Republics (Rосси́йская Сове́тская Федерати́вная Социалисти́ческая Респу́блика; 1922), which existed until 1991. These changes in the names undoubtedly reflected the complete transformation of the state, so the function of the name change is an indication of the new situation. Modernization of traditional empires in crisis and transformation of large historical states into modern ones also force a change of name, for similar reasons, as it has been shown in the case of Persia which became Iran in 1935, that of Siam which became Thailand in $1939,{ }^{11}$ or that of Abyssinia which became Ethiopia in 1941. The function of the name change is the same.

The disintegration of the compound states has so many ways, expressed in different naming methods as well, that there is no way to detail them here. I just mention the dissolution of Austro-Hungarian Monarchy in 1918/1920, and the intricacies of the naming of the successor states, like Austria, a republic, Hungary, in principle a monarchy, practically a "kingdom without a king", and Czecho-Slovakia (later Czechoslovakia), two republics in federation with each other. Between 1920 and 1944 the official name of the Hungarian state was the "Kingdom of Hungary" and this term was used in different ways; e.g. in the name of state organs, courts, authorities, and offices; even public notaries were "royal notaries"; it was written

\footnotetext{
11 States are sometimes renamed permanently or temporarily to their former or original names; thus, for example, Thailand was renamed Siam between 1946 and 1948.
} 
on the cover of passports, etc. In the linguistic practice, however, the country name, "Hungary" was preferred and made part of the semi-official practice, e.g. printed on postal stamps or used even in international treaties. The reason for this was probably the aim to conceal the contradictions of the political and legal situation about the form of state established in 1920/21, designed to be a temporary solution, but lasting for 24 years. ${ }^{12}$ Other functions of this tricky combination of the two names were the result of its dual nature: the official name (referring to monarchy) was to carry on the historical tradition, so that it could be traced back to the foundation of state in the Middle Ages, and the country name as a semi-official name was to give the people a new identity, based on a fictitious territorial vision rooted in the past as well.

Another typical case in this second group is the naming, sometimes renaming states during the time of colonial independence. Here too, the duality of traditional naming and giving a new identity causes some tension. In many cases, these states have chosen a new name in the process of becoming independent. ${ }^{13}$ Some of those, however, who have not done so, later might have changed their mind, because they would have liked to obscure or forget their colonial past. This was the case of how Dahomey became Benin (1975), Upper Volta became Burkina Faso (1984), and Ivory Coast declared to accept only the French version of its name in every language, so became Côte d'Ivoire (1986).

The third main type can be exemplified by changing the name of Italy and Japan (both in 1946), naming the Régime de Vichy (1940), and renaming Hungary (2011). They are so different that the function of renaming must be looked at separately in each case.

The Italian state was renamed by a new constitution, approved by referendum, in 1946 (in effect 1948). Then the Kingdom of Italy (Regno d'Italia) became the Italian Republic (Repubblica Italiana). In a similar vein, but not always by referendum, the name of the Greek state changed five times during the twentieth century (in the years 1920, 1924, 1946, 1967/1973, and 1975) due to the hectic political changes of that country. In both cases, the new names reflecting the forms of states indicated future changes in the political and administrative system.

The case of Japan is interesting because it shows, that it may happen that in the course of a significant constitutional change the form of state is left unaltered while the state title changes. After the Second World War, the name of the Empire of Japan changed to Japan - without any indication as to the form of state. Constitution of Japan (promulgated in 1946, enacted in 1947, and has never been amended since) uses the word "Japan" as state name only in its title and in two of its penultimate substantive articles [54: art. 97-98.]. On the basis of this constitution, the

\footnotetext{
12 Hungary in this period was "governed by a temporary regent whose position was permanent"-commented an analyst sarcastically; see [2: 10].

13 This was the case, for example, when the Dutch East Indies became Indonesia (1945/49), Northern Rhodesia became Zambia (1964), Southern Rhodesia became first Rhodesia (1964) later Zimbabwe (1980), Nyasaland became Malawi (1964), Bechuanaland became Botswana (1966), Basutoland became Lesotho (1966), Gold Coast became Ghana (1957), Togoland (which was a part of Gold Coast) became Togo (1960) British Honduras became Belize (1973), Ellice Island became Tuvalu 1978, Gilbert Island became Kiribati (1979), and New Hebridas became Vanuatu (1980).
} 
country name and state title of Japan are analogous, at least in the world's main languages, ${ }^{14}$ thus, it does not contain any supplement pertaining to the form of state (form of government) or other public law factors. In a way, this can be called a "reticent wording" if we have in mind that before 1945 the Japanese constitution contained such a supplement. During the period between the beginning of the so-called Meiji Restoration (1867) and the end of the Second World War (1945), the long form of the state name of Japan was Empire of Japan (in other variants: Empire of Greater Japan; that is, Dai Nippon Teikoku, 大日本帝國). In my view the new name of 1947, namely Japan without the word of "empire"-in the context of pre1945 history, and with that in mind that the form of state (form of government) of Japan has remained monarchy ("empire") even after 1947—can be considered a "reticence" about the information concerning the role the Japanese emperor played in the Second World War.

Most enigmatic are the cases whereby the form of state does not change to its reverse (i.e., from monarchy to republic or vice versa), but the name-giving power omits the form of state from its name either by supplementing it with a seemingly neutral word, e.g. with "state" or "commonwealth" or by putting the country name into the position of state title. This indicates that significant changes are to occur in the political system. It is only possible to determine the actual motive behind such a move in retrospect, while it generally takes place in case of a stealthy system change. I give here two characteristic examples of this issue.

The first was the case when Marshal Pétain changed the name of the French Republic to the French State (l'Etat français) in 1940. At the time of this change, it was not clear whether it constituted a part of the right-wing "national revolution" or it was a sign for the restoration of the monarchy. Nevertheless, the person of the omnipotent prime minister was accorded cultic honors while the state in its appearances had already resembled an old-style monarchy. The question of whether Pétain would have restored monarchy or not has been left open as its system was blown away by the winds of history. The second example is provided by the renaming of the Hungarian state in 2011 whereby the name Republic of Hungary was changed to Hungary. Details of this issue will be discussed below.

\section{Changing the Name of Hungarian State}

\subsection{Changing Names of the Hungarian State During the Twentieth Century}

Renaming the Hungarian state in 2011 was the seventh change in the name of the state within the time horizon of a 100 years. The six earlier cases during the twentieth century (in the years 1918, 1919, 1920, 1946, 1949 and 1989) were not only the times of name changes, but signify the key turning points of the history of Hungarian nation, and also the main changes in the form of state (form of government). The

\footnotetext{
14 This addition needs to be made because in Japanese language the name of the Japanese state is 日本 国 (Nippon-koku or Nihon-koku), which is literally the State of Japan.
} 
lack of change in the form of state, however, does not mean that the change in the state name is not be related to the substantial transformation of the political system since a particular state form, both the republic and the monarchy, may give way to several political systems. The 2011 change of the name of the Hungarian state was a by-product of a change not in the form of state but in the political system. Therefore, its significance-in contrast to the official view and the interpretation of a few analysts-is not at all symbolic, inasmuch as it is taken in a "solely symbolic" and "not too important" sense, but very much essential.

The inevitable connection of the public legal nature of state power and renaming the state in modern history of Hungary can be illustrated as follows: see Table 1.

I make three additional comments on the interpretation of this table.

(a) As to the name of the Hungarian state before 1918, we have to keep in mind that the state name, just like the state itself, is a modern phenomenon. Before modern times formations of public power regarded as states were denoted according to the personal or the territorial aspects of domination. Therefore, the medieval Archiregnum Hungariae was comprised of several regnums (kingdoms), apart from Regnum Hungariae; e.g. in the time of Andrew II of Hungary (thirteenth century), they amounted to seven, later to two. At the time of the AustroHungarian Empire, the country name Hungary was rarely used to denote the Hungarian state; instead, especially in emphasizing the situation and relation of the country within the Empire, the term Lands of the Crown of Saint Stephen (German: Länder der Heiligen Stephans Krone, Hungarian: Szent István koronájának országai) was employed. The Act XVI of 1867, establishing the Austro-Hungarian Empire from the Hungarian side, used the name A magyar

Table 1 Names of the Hungarian state during the $20^{\text {th }}$ century and at present

\begin{tabular}{|c|c|c|c|c|c|c|c|c|}
\hline & before 1918 & 1918 & 1919 & $1920 / 21$ & 1946 & 1949 & 1989 & after 2011 \\
\hline $\begin{array}{r}\text { FORM } \\
\text { OF } \\
\text { STATE }\end{array}$ & monarchy & republic & $\begin{array}{c}\text { Soviet } \\
\text { republic }\end{array}$ & monarchy & republic & $\begin{array}{l}\text { Soviet } \\
\text { republic }\end{array}$ & republic & $\rightarrow$ \\
\hline $\begin{array}{r}\text { STATE } \\
\text { NAME } \\
\text { (state title) }\end{array}$ & $\begin{array}{l}\text { Kingdom } \\
\text { of } \\
\text { Hungary }\end{array}$ & $\begin{array}{c}\text { People's } \\
\text { Republic } \\
\text { of } \\
\text { Hungary }\end{array}$ & $\begin{array}{l}\text { Hungarian } \\
\text { Allied } \\
\text { Socialist } \\
\text { Soviet } \\
\text { Republic }\end{array}$ & $\begin{array}{c}\text { Kingdom } \\
\text { of } \\
\text { Hungary }\end{array}$ & $\begin{array}{c}\text { Republic } \\
\text { of } \\
\text { Hungary }\end{array}$ & $\begin{array}{c}\text { People's } \\
\text { Republic } \\
\text { of } \\
\text { Hungary }\end{array}$ & $\begin{array}{c}\text { Republic } \\
\text { of } \\
\text { Hungary }\end{array}$ & Hungary \\
\hline $\begin{array}{r}\text { COUNTRY } \\
\text { NAME }\end{array}$ & Hungary & Hungary & Hungary & Hungary & Hungary & Hungary & Hungary $\pi$ & Hungary \\
\hline
\end{tabular}

As for the overlapping of the meanings of some terms, it is enough to make two short additions here. 1. The Soviet republic [Tanácsköztársaság] of 1919 was officially called "republic of councils" (German: Räterepublik), while the Soviet republic [Népköztársaság] of 1949 was officially a "republic of people" (German: Volksrepublik), respectively. 2. The expression People's Republic [Népköztársaság] of 1918 could be explained by the legitimacy objective assigning the people as the source of power (in contrast to that time cracked down monarchical legitimacy), and not by some special theoretical considerations regarding the form of state (form of government). The expression People's Republic [Népköztársaság] of 1949 was used to bypass the usual but not too popular terms of the type of political order, e.g., the dictatorship of the proletariat, Soviet state, etc., exported by the Soviets to Eastern Central Europe in the mid-twentieth century.) 
korona országai (Lands of the Hungarian Crown) to denote the Hungarian state and not the Kingdom of Hungary.

(b) On 16 November 1918, at the proclamation of the republic, the National Council, which could be considered as the constituent body, used the term "people's republic". However, in the subsequent 4 months, the Hungarian state was referred to both as "people's republic" and "republic". Initially, the Council Republic proclaimed on 21 March 1919 was simply called the Republic or the Hungarian Soviet Republic. Although for ca. 10 days its long-form of state name was the Republic of Hungary, from 2 April 1919 on (pursuant to the temporary constitution, Decree XXVI of the Revolutionary Governing Council) the name Republic of Councils (Council Republic) was employed. The state name in the constitution, which was intended to be "final" but remained in force for ca. 40 days and was adopted on 23 June 1919 by the National Assembly of Soviets (Councils), was Hungarian Allied Socialist Soviet Republic. After the fall of the Republic of Councils on 1 August 1919, the government of Julius Peidl defined the state form right away, on 2 August 1919 again as "people's republic" and the state as Hungarian People's Republic. The following government of István Friedrich changed the state name to the Republic of Hungary on 8 August 1919 despite the fact that the name Hungarian People's Republic also remained in use during his governance.

(c) In 1920, the text of Act I of 1920 "restoring constitutionalism (after the revolutions)" did not elaborate the long form of the state name. The underlying reason was probably that in February 1920, at the time of adoption of this act, legislators did not yet know what form of state (form of government) the victorious powers of the First World War would prefer: republic or monarchy. During the peace talks, the name of the Hungarian successor state of the Austro-Hungarian Empire-like that of Austria ${ }^{15}$ earlier-underwent changes. Whereas the preparatory acts (made during the year 1919) of the Trianon Peace Treaty used the name "Hungarian Republic" for the future "signatory party", the finalized version of the peace treaty signed on 4 July 1920 did not refer to the state form and denoted the new state on the basis of the country name ("Hungary"). ${ }^{16}$ Former prime minister Stephen Bethlen recalled it in 1925 in the following way:

\footnotetext{
15 In this similarity, however, there was an important difference. In the case of Austria, the problem was with the country name (originally German Austria: Deutschösterreich or Deutsch-Österreich), and not with the state title (republic), whereas in the case of Hungary the problem was with the state title (as to the intentions of the national delegation: kingdom), and not with the country name (Hungary). At the collapse of the Austro-Hungarian Empire, the name of the Austrian successor state was initially German Austria. The National Assembly of German representatives declared on 12 November 1918 that "German Austria is a democratic republic" and consolidated this name in the temporary constitution of 14 March 1919, as well. The name German Austria (Deutsch-Österreich), however, was not approved by the allied powers (the Entente) - presumably by reason of the frightening idea of the so-called greater Germany solution (Großdeutsche Lösung)—expressed their intention in May 1919 to conclude the peace treaty with the Republik Österreich (Austrian Republic). See the telegram of Chancellor Renner [32: 194] as cited in [22: 14].

${ }^{16}$ For the analysis of Treaty of Peace between the Allied and Associated Powers and Hungary (Trianon, 4 June 1920) in the context of international law, see [23].
} 
"for whereas in its first draft of the Conditions of Peace it spoke everywhere of a Hungarian Republic, the Treaty of Trianon contains no such definition but speaks of our country throughout, without any designation of the form of government, simply as » Hungary «" [6: 450]. In Hungarian law, monarchy as the form of the state was first declared by the prime ministerial decree of 18 March 1920 (2394/1920. M. E.), establishing — and, in a peculiar way for legislation, "explaining" - that the state form of Hungary is a monarchy. At the legislative level, slightly paradoxically, it was the Act XLVII of 1921 (adopted on 6 November 1921) declaring the dethronement of the House of Habsburg that established, or at least reinforced that the state form of Hungary is a monarchy.

I add to this, that there was a duality in the use of names between 1920 and 1944. Although the name of the state, in principle and officially, was "Kingdom of Hungary", in practice in many contexts the name "Hungary" was used, as I explained in some detail in Sect. 1.2, in order to conceal the paradoxies of the "kingdom without a king" situation. (On the problem of "monarchy without a king" see [37].) So the 2011 renaming had some interwar reminiscences, as well, inasmuch as it was an informal practice at that time to call the state by country name, and the 2011 change was pointing in that direction, too.

Turning to the current situation, Table 1 clearly demonstrates that the 2011 change in the state name evolved in a way that constitutional drafters introduced a new naming practice, not a new name: they qualified the country name as state name. It is important to note that on the basis of the country name, the Hungarian state could have been called in any context by its short form of state name "Hungary" even before 2011, so this re-qualification was in the linguistic-grammatical sense unnecessary. Therefore, it can be stated that the Fundamental Law of 2011 did not, in fact, rename the state but made it impossible to use the name "Republic of Hungary", or significantly reduced the possibility thereof. (See Sect. 3.2, below.) In a sense, the name change was used to suppress the word "republic", and in this way, republican values in public discourses, making it impossible or harder to interpret the political community according to these values.

\subsection{The Way of Renaming the Hungarian State in 2011}

According to Article A of Chapter Foundation of the Fundamental Law of Hungary adopted in 2011, "HAZÁNK neve Magyarország" (in Hungarian). This short sentence can be translated into English in two ways depending on the equivalent we find for the word "hazánk". The official English translation of the text uses the words "our country" while a translation attached to a commentary written by authors who qualified themselves as "friends of the Fundamental Law" translates it as "our homeland".

According to the former translation, the provision in question reads as follows: "The name of OUR COUNTRY shall be Hungary" [56: 3], while according to the latter: "Our HOMELAND shall be named Hungary" [3: 347]. The former prefers good style to the exact matching of words while the latter prefers the exact matching 
of words to style and, not incidentally, to accurate translation. In fact, the second version would sound precisely as follows: "The name of OUR HOMELAND shall be Hungary", but this difference is irrelevant now. The argument that it is not about a simple question of translation techniques but about semantic disagreement motivated by political views will be discussed below.

This short sentence indicated the renaming of the state for the following reasons:

- in Hungarian, just like in every language, there exists a general natural semantic relationship between country and state, and between country name and state name;

- in some languages, for instance in Hungarian, mainly in political discourse the meaning of the word homeland can be, in principle and at the cost of some distortion in communication, extended to the "state" with the transmission of the word country;

- the constitutional power expressly included in the official explanatory note accompanying the bill of the Fundamental Law that it aimed at renaming the state, and not the county or the homeland [65: 35].

Adoption of the constitution in 2011 was followed by the changing and amending laws and other legal rules in line with the new provisions of the Fundamental Law, among them, what concerned the name. This meant that the earlier name of the state had to be rewritten in the various legal rules. Most of the work was done by the drafters of Act CCI of 2011 [59]. This law of gigantic size, including 437 sections, amended the text of 307 other laws. Apart from providing for thematically not interlinked provisions, it undertook three objectives regarding "words". It

- replaced the term "Republic of Hungary" with the word "Hungary" in the text of hundreds of laws ${ }^{17}$;

- replaced the names of organs of governments and other public bodies modified by the Fundamental Law in the text of hundreds of valid laws with the name of those newly established, for instance, changed the name of Supreme Court to that of the old-sounding Curia, ${ }^{18}$ etc.,

- eradicated or at least made it rare the words constitution, constitutional and related words such as unconstitutional from the text of the valid Hungarian laws as much as it was possible. It has changed the word "constitution" to "fundamental law", it

\footnotetext{
17 For the legal system as a whole, this work also had to be done at the level of governmental regulations. This was done by a decree [c.f. 64], entered into force on 1 January 2012. It performed the same function at the level of administrative regulations as the law mentioned above: it changed the name of the state in the text of numerous other governmental decrees, and made fewer of the expressions that were related to constitutionality.

18 It worth noting that the original name of the highest court before 1945 was not "Curia", but "Royal Hungarian Curia"; the word "royal", however, was not revitalized in 2011. Renaming of particular administrative organs and different courts has started in the period of constitutional democracy, between 1990 and 2010. See on this [47: 13-15] (2014) and [26].
} 
has often replaced the word "constitutional" with "legal" or "lawful", and sometimes changed the term "unconstitutional" to "anti-fundamental law". ${ }^{19}$ (As the Fundamental Law did not render it illegal or illegitimate to use the words "constitution" and "constitutional" in Hungary-it has even referred to constitutional values and the historical constitution, recognized the institution of constitutional complaint as well as the constitutional court as institution-, it could be the subject of a separate analysis what considerations influenced the drafters of the text of Act CCI of 2011 in their "eradication" and "rarefaction". So far, no such analysis has been undertaken.)

The Fundamental Law entered into force on 1 January 2012. Tables at border crossing points on highways, driveways and along rivers, as well as other inscriptions indicating the state borders were replaced in the last days of 2011. Courts and organs of public administration were renamed, their buildings got new signboard by the end of 2011 .

The Hungarian Committee on Geographical Names officially determining country names and state titles as "geographical names" was disbanded in 2011 and reorganized in early 2012, and the new composition committee accepted its resolution in March. As to the resolution "it acknowledged" that according to the Fundamental Law the state is called "Hungary", and modified the official list of country names, which is a list of state names as well, accordingly. The government, through its appropriate bodies, communicated the new name to the United Nations and the states with which Hungary had diplomatic and other kinds of relations, and notified the international organizations about the change. The renaming of the Hungarian state thus legally has taken place. The duration of this process, conceived in legal terms, has taken only a couple of months. Certainly, the renaming the state in a social and political sense has taken much more time.

The renaming of a state can be considered as socially complete as soon as the new name is used in all the contexts where the state name typically appears or should appear. Renaming a state in this sense requires years because the names of states appear in thousands of places: not only on inscriptions, on the boards of the coat of arms placed at the entrance of institutions, and on official stationery, but on identity cards and passports, on coins (not on banknotes in Hungary), sometimes on stamps of national post office (not in case of Hungary), and so forth-not to mention the everyday language usage of citizens. It changes from country to country whether the name of the state is included in the names of public companies and other enterprises, national railways, public schools, publicly maintained artistic ensembles or parks in public management. It is highly costly to change all of them: it does not come cheap to rename a state.

\footnotetext{
19 These changes were linked to the fact that in 2011 the conceptual relationship between the "fundamental law (basic law)" and the "constitution" was unclear both among the drafters of the new constitituon, and among Hungarian scholars of public law. Some have speculated that the constitution is part of the funadamental law, while others supposed that the two concepts refer to the same phenomenon. These conceptual uncertainties have not yet been clarified since that time. See on this [51: 8].
} 
Therefore, those renaming the Hungarian state decided-with some late wisdom in 2013 - to display the new name on the aforementioned places and objects only after the "natural wear of inscriptions" containing the state name, thus, for instance, after the continuous change of identity cards. This continuous replacement of the documents, coins, coat of arms of different institutes, etc. was provided for in a provision, the most difficult to understand in the Hungarian legal system, namely in the fourth amendment of the Fundamental Law adopted on 25 March 2013 using a slightly euphemistic reference to "principles of responsible management".

According to the almost incomprehensible Article 20 of the 2013 constitutional amendment, "[A]fter the entry into force of the Fundamental Law, the name referring to the Republic of Hungary may remain in use as a reference to Hungary in accordance with the legal regulations in force on 31 December 2011, until the transition to the use of the name under the Fundamental Law can be achieved in accordance with the principles of responsible management". This wording is not only stylistically but also semantically problematic for the Hungarian state was at that time, and still is a republic; therefore, the word "Hungary", in fact, is an appellation "with reference" to the Republic of Hungary (perhaps we should say "to a republic of Hungary"), as well. ${ }^{20}$ On the basis of this text, one may even suggest that the legislature did not simply remove the word "Republic" from the state title, but even prohibited its use. Of course, formally it was not a formal legal prohibition, but the legislature worded the text of the law as if it were forbidden. The Hungarian state can still be called "Republic of Hungary", instead of "Hungary" in non-legal texts, but this might sound like a protest against it, ${ }^{21}$ or might be misunderstood in different contexts.

Although no relevant sociological surveys have been made, it can be established by way of simple observation that it took the new name a couple of years to be put into use and be reflected in the linguistic practice. In the case of Hungary, it has become manifest during the past years sociolinguistically that it took place, and by now-except the political parlance (which can be interpreted as a part of social language usage as well)_it has been completed.

Finally, we can ask: has the renaming taken place politically as well? Perhaps it would be better to put this question this way: has the renaming been finished in the political sense by now? The renaming of a state can be argued to be politically complete and finished if

(1) the new name is generally accepted not only in the official language but also in the everyday language usage, without specific pressure,

\footnotetext{
${ }^{20}$ It would have been not only more classy but also more straightforward, thus intelligible, to use one of the following terms instead of that burdensome phrase ("the appellation with reference to the Republic of Hungary when referring to Hungary"): "the former name of state containing the state form of the republic", or more simply and calling things by names, "the name Republic of Hungary".

21 Therefore in the light of this wording of the rule, moving on the fringe of declaring something partly legal, partly illegal or non-legal, and qualifying a particular denomination of the the state accordingly, it was a meaningful wording to call the Fundamental Law of Hungary (2011) the "Constitution of the Republic of Hungary”, in an article published in 2013. See [40: notes 33, 35, 37, 38 and 41].
} 
(2) there is a generally felt consensus beyond this and manifested through speech in everyday language usage,

(3) the old name is not used for the critique of the political conditions of the state denoted by the new name. This third criterion belongs to the problem of social and political remembrance and forgetting, and it is impossible to deal with enough detail here.

According to criterion (1), the renaming of the Hungarian state can be considered as complete since people from all walks of life generally use the word Hungary instead of the Republic of Hungary in their everyday speech acts. Regarding criterion (2), the renaming is only partially complete as a significant part of politically different groups accepts changes while another part still accepts them only with reservations. (In this regard, accurate sociolinguistic surveys have not been undertaken; but even in their absence it can be stated that the distribution of groups supporting and opposing the government policies after 2011 roughly corresponds to the ratio of groups supporting and opposing this change in language.) As for the criterion (3), the term "Republic of Hungary" - in a positive context: as memory or objectiverelatively often appears in public demonstrations criticizing the new regime or some aspects of it, as a subject of political nostalgia and generally as a critique of the current situation. In this regard, the renaming of the Hungarian state in a political sense cannot be considered complete at all.

I put forward the idea, that there is a fourth area of surveying the completion of the name change. This seems to be legal, though it is undoubtedly political. This is the performative utterances used by courts in the delivery of judgments. For it is connected to the repression of any item of the Republican language, I will come back to it later, in Sect. 3.2.

\section{Circumstances, Consequences, and Reasons for the Change}

\subsection{The Semantic Background of the Renaming the Hungarian State}

The renaming of the Hungarian state took place with the utilization of two semantic interrelations. The first concerns the exploitation of the overlapping semantic relationship between the words country and state while the second relates to the special interconnection between the concepts of homeland and state. Figures 1 and 2 illustrate these interrelations which are explained in detail below, under points A and B.

A. In many languages, the word country has a dual meaning: it refers, on the one hand, to the geographical territory and its complementing parts, and on the other hand, to the established institution called state. In other words, the state is not the exclusive reference of the word country. ${ }^{22}$ In most languages, the word state also

\footnotetext{
22 This wording and terminology_namely, that a word with one sense (German: Sinn) can have different references (German: Bedeutung) — can be traced back to the analysis of Gottlob Frege. See [13: 29-31].
} 
has a dual meaning referring to the institutionalized power and a certain authority, as well as to a particular geographical territory and its population.

This is why the state can be-among ideal circumstances-denominated on the basis of the country name and the country can be-among ideal circumstancesidentified on the basis of the state name. Under different circumstances, however, the two meanings - in the case of both words - may be in conflict with each other. In most cases, natural language usage easily resolves this semantic conflict. In case of such semantic conflict, in the case of the country name the territorial component will be emphasized while the institutional element becomes subordinated, whereas in the case of state name or state title the institutional component will be emphasized with the territorial element being subordinated by that. The semantic complexity of these two words facilitated the linguistic handling of politically divided peoples, such as the Korean, and the German in the past, of politically divided territories, like the island of Ireland, or of territories and peoples with temporarily suspended states. In this latter sense, we still use the word Poland as a country name for a territory divided by great powers.

It is important that there is no general rule in any language that defines when to use the country name and when to use the state name (state title) for identifying the state. There is no such rule in international law or in the national legal system of Hungarian either. In international treaties, e.g., the Hungarian state was usually referred to as "Hungary" (not the "Kingdom of Hungary") during the 1930s and as the "Republic of Hungary" (not Hungary") during the 1990s.

Those renaming the Hungarian state in 2011 exploited this semantic complexity and the resulting flexibility of the country name. As is shown in Table 1, drafters of the Fundamental Law have put the country name "Hungary" into the position of the long form of state name or constitutional state name in 2011, thus prescribing that the Hungarian state cannot be denominated on the basis of its state form, namely as a republic. Whatever the aim of constitutional drafters was (I have hinted at this before, and will detail it later), it was to be achieved solely by an awkward and clumsy linguistic remedy, which is still sometimes under the necessity to claim that "the name of Hungary (as a state) is Hungary". 23

\footnotetext{
23 Therefore, it is no wonder that supporters of the renaming of the state (and among them the apologists of the post-2010 Hungarian political system) attempt to remove this linguistic clumsiness by employing various trickeries in argumentation. For instance, according to the author of a publication that serves as a training book for future political leaders, "with the state name »Hungary«, the Constitution [the Fundamental Law] abolished the linguistic dualism of country name and state name" [52: 51 (first ed.) 65 (second ed.)]. This is, however, a "nonsense upon stilts" since the naming system of states applies to 195 states while the drafters of the Fundamental Law-whose power extends within the borders of Hungary-have not been in the position to change this international practice. Therefore, it is not only an obvious mistake but a fallacy, maybe misleading apologetics to claim that "there is no point to distinguish between country name and state name anymore". Ibidem. Quite opposite, the point to distinguish these two categories is to realize the background reasons for changing the name of the state.
} 
B. The drafters of the Fundamental Law, however, could not state in their text that "the name of Hungary as a state is Hungary". Thus, they employed a different tool in order to arrive at a solution. They provided that "[ $\mathrm{t}]$ he name of OUR HOMELAND shall be Hungary", thus establishing a link between the meaning of the word homeland and the concept of state.

This link would not be facilitated by natural language usage, however. In order for this sentence to be considered as the renaming of the Hungarian state, a deviation had to take place from the natural semantics of language. In the given case, this happened in a way that the drafters incorporated the word "homeland" in the context of "country" and "state", thus homogenizing the meaning of the words country and state. This is a characteristic method of political parlance.

In every day (non-political) language usage, homeland stands for the land where one was born together with all the positive feelings one feels for that, as well as for the place where one gets along, thus considers it his home both emotionally and culturally. It is a place or wider region one is attached to culturally by reason of his birth or growth, socially by reason of his progress in life, and emotionally in both cases. Normally, it does not refer to the state because the word homeland has a personal meaning, while-in modern societies for the majority of people-the meaning of the word state is impersonal and institutional. ${ }^{24}$ Therefore, for people socialized under Hungarian linguistic conditions seeing the world in the semantic framework characteristic for Hungarian culture, the sentence "[t]he name of OUR HOMELAND shall be Hungary" means neither that (a) "the name of the Hungarian state shall be Hungary" nor that (b) "from now on, the name of the Republic of Hungary shall be Hungary".

The territorial component of the word country may create some very general link between the meanings of homeland and state: namely, homeland relates either to place of birth (viz., through one's parents) or to the place where one grew up. In order for this link emerging, the word homeland had to be put in the context of state, thus it had to be politically reinterpreted: the place where one was born and grew up constitutes not only his homeland but also his state.

Such wording had a precedent in Hungarian political discourse, namely in the 1970s' Communist Hungary. To illustrate it with a single example from the period in question, one of the slogans of the Communist Party for the 1st of May parade was the following: "Long live and thrive our beloved homeland, the Hungarian People's Republic!" For most of the people, the Hungarian People's Republic meant not their homeland but the state under whose authority they lived. Considering the interrelation above, their homeland was Hungary. With this slogan, the Communist Party aimed at transferring the positive emotional commitment from the homeland to the state. This transfer was facilitated by the fact that the homeland was denoted with the long form of the name of the state. This artificially constructed linguistic practice attempted to legitimize the political regime of that time. The same technique was used in other Communist countries, as well. In the German Democratic

${ }^{24}$ For a detailed evaluation of this issue, see [44: 1-10]. 
Republic, for example, this slogan was issued at a national holiday in 1986: "Alles für unser sozialistisches Vaterland und für die Sicherung des Friedens" ("Everything for supporting our socialist homeland and for ensuring peace") [66: 1]. See also the text of the national anthem of the GDR, written by Johannes R. Becher, which also operated on the term Vaterland (homeland) [5: 61].

At the renaming the Hungarian state, the drafters of the Fundamental Law in 2011 - certainly with a different purpose, and probably unconsciously-engaged in continuing this linguistic practice of the Communist past. Figure 2 shows the semantic scheme of reinterpreting linguistic meanings with a political purpose.

\subsection{The official justification and actual reasons for name change}

Regarding the debates on the renaming of the Hungarian state, that took place mainly in the first half of the past decade, it is worth making a distinction between official and non-official justification. The renaming was one of the first steps in the transformation of the Hungarian constitutionalism, public law, and political system. Since the actual course of the transformation — due to its stealthy nature [c.f. 33] was apparent only later, the proponents of the official view might have considered it important in 2011 to hide the motive of renaming. The "official view" emphasized one or more of the following three claims and arguments. ${ }^{25}$

Firstly, it was said that that the renaming enhanced or expressed historical continuity. ${ }^{26}$ The disputable nature of this claim was referred to above when I noted, the country in question was called "the Land of the Crown of Saint Stephen" even though the name "Hungary" was also employed. The grammatical root of the words of the country name- the adjective constituting the basis of both the so-called exonym (English: Hungary, German: Ungarn, French: Hongrie) and the endonym (in Hungarian: Magyarország) —is undoubtedly very old. The name of the nation (Hungarian: Magyar), however, became interlinked with the word "country" (Hungarian: ország) relatively late. For these reasons, the name of the country in question has not been Hungary "for a thousand years"- even though the word Magyar and its equivalents in foreign languages have a very long history. I add to that here that the renaming of the state in 2011 - as it is apparent from the above-constituted not historical continuity, but was, on the contrary, the interruption of continuity. It interrupted a century-old tradition that was based on the distinction between the country name and state name and introduced a new naming practice. The argument of

\footnotetext{
25 The official view is available in [43]. In this context, the term "official" means that these arguments were formulated, uttered, and emphasized by those decision-makers, who have the job and responsibility to justify legislative decisions. One of the talking partners of this conversation was a member of the European Parliament and presumably a drafter of the constitution, the other one is a Member of Parliament in Hungary.

26 As József Szájer argued in an interview, "[r]egarding the renaming of the country, it is the sign of continuity [...], it is evident that Hungary's name has been Hungary for a thousand year; [therefore] this continuity is better expressed by a name disregarding the [republican] form of state" [43: 59].
} 


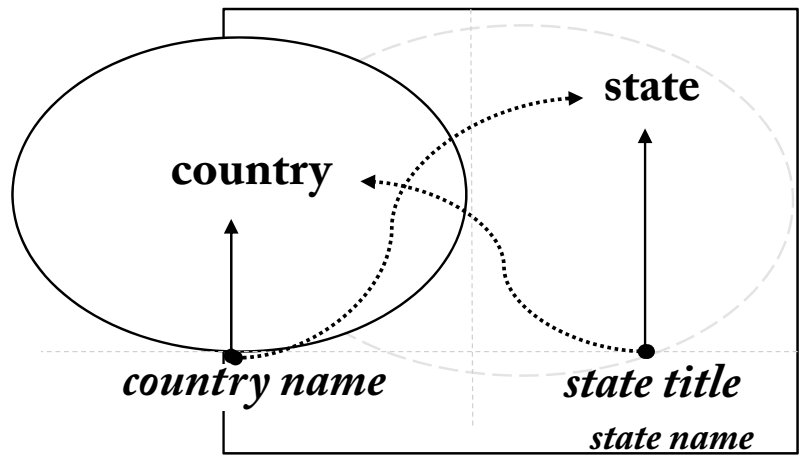

Fig. 1 Semantic difference between the words country and state in standard usage

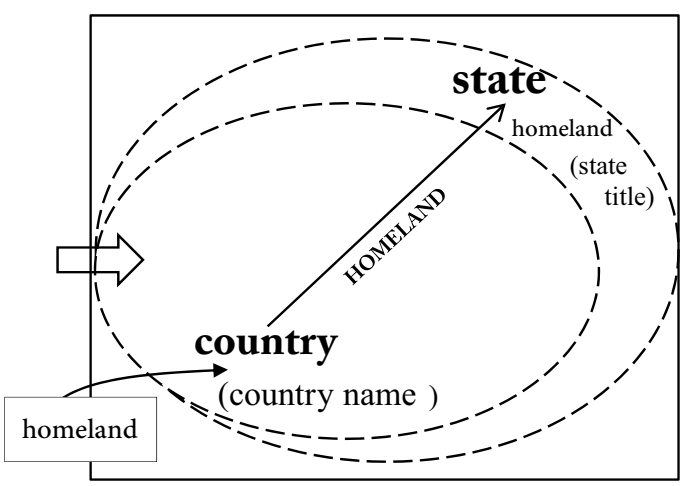

Fig. 2 The semantics of the words country, state, and homeland in political usage

historical continuity is disputable also on the account that the Hungarian state could be called Hungary already before 2011—without changing of the long form of state name or constitutional state name.

Secondly, it has been emphasized that the renaming was-as they said- "only symbolic", either in the sense that it was some trivial thing not affecting the essence of the matter as it does not change the state form $^{27}$ or in the sense that the correct use of symbols was also politically correct and effective. ${ }^{28}$ Constitutional lawyers committed to the new system, or (as they call themselves with some controversial ambiguity) "friends of the Fundamental Law" emphasized the "symbolic

\footnotetext{
27 Similarly, as József Szájer argued, "[i]t is not about our aim to change the state form” [43: 59].

28 According to Gergely Gulyás, "[e]veryone can admit that it is worth using symbols that the country's citizen feel attached to and employ. And so far, everyone has regarded Hungary and not the »Republic of Hungary « their homeland" [43: 61].
} 
importance" of the renaming: as an analyst argued, the renaming "aims at narrowing the gap between the country and the State. Patriotism in Hungary means that most Hungarians have an emotional tie to the country, whereas it does not mean that they have any kind of relation to the State. The new wording envisages a stronger connection between country and State: one cannot be a good patriot without being a good citizen." [34: 59]. It is true that there is a significant discrepancy between the relation of citizens to the country and the state in Hungarian society, but this can only be remedied by a state policy following the right principles, democracy, openness, rights, etc., and not by renaming the state.

Thirdly, it often appeared in the official argumentation justifying the name change that the cessation of the name "Republic of Hungary" did not mean the intention to change the form of state, namely the restoration of the monarchy. As it has been argued, there is "no political need and intention for such a thing in Hungary" [43: 59]. A scholar used similar wording in the academic literature of constitutional law: "The change [of the name of the state] does not suggest the consideration of changing the form of the State (re-establishment of the monarchy)—Hungary remains a republic (...)" [34: 59]

Since the critique of republican ideas had been present in Hungarian political struggles for years, the other side of the debate did not regard this argument sincere and thus feared the restoration of the monarchy for different reasons. ${ }^{29}$ Therefore, proponents of the official arguments were obliged to prove their intentions. This led to a situation where the official view regarding the question of the republic became flexible, or rather pliant: they emphasized that the idea of the republic was historically insignificant in Hungary; however, constitutional drafters did not choose a different form of state, namely monarchy, for the country. In a similar vein, the "republic" was not worthy to be included in the state title but for some reason, it was worthy to remain as the form of state after the adoption of a new constitution.

This elastic argumentation highlighted a specific interrelation which later became apparent, although it has never become the official view. Namely, that the aim of the renaming of the state was to further weaken the already frail republican tradition in Hungary. ${ }^{30}$ By that - according to the actual intention of constitutional draftersthe change might have contributed to the legitimization of the planned new political regime to some degree and so helped distinguish it sharply from the earlier constitutional democracy. If true, it confirms that in the Hungarian political elite there is a relatively widespread belief that the republican ideas do not have enough potential for legitimization; therefore, it might be useful to emphasize the opposite and to revive some formalities of monarchical tradition. And it is well known that monarchical formalities do not always require real monarchs.

\footnotetext{
29 As Viktor Orbán argued in 2006, then as leader of the opposition, "for us, the republic is an empty word, (...). Our future is in the nation and not in the republic (...)" [67: 1]. The wording of a politician in 2011 was as follow: "The republican form of state did not play such a role in Hungarian history, it does not have a surplus content that would justify its emergence in the country name" [43: 59].

${ }^{30}$ In this regard, an analyst stated in 2018 that "the exclusion of the term republic from the constitutional state name can also be interpreted as the departure from republican ideas and traditions" [50: 71].
} 
It is not a coincidence that five states, all in the region of Central Eastern Europe, do not include the word republic in the long-form of their state names (state titles) or constitutional names - despite all be republics. Currently, these are Bosnia and Herzegovina, Hungary, Montenegro, Romania, and the Ukraine. And we may include here a sixth one, the Polish state. Its state title in Polish is Rzeczpospolita Polska, and the word rzeczpospolita is generally translated to several languages as republic despite the fact that its English equivalent would be, in fact, commonwealth. ${ }^{31}$ The word rzeczpospolita currently means for the Poles republic but there was a time when it referred to a kingdom. So Rzeczpospolita Polska can be translated into English not (only) as Republic of Poland, but as Commonwealth of Poland (too).

To sum it all up, I claim that these countries aspire to a state of political existence somewhere between the monarchy and the republic which I will detail in the next section. All this is not to say that a change of the form of state is to be expected in these countries in the near future, but rather that some of them are keen to revive the monarchical traditions and establish public law systems that can be qualified as a transition between the republican and the monarchical order. If this is plausible, Hungary is one of these countries.

Before turning to this mixed or transitional public law system I return briefly to the problem of the way of delivering judgments by the courts, which I have dropped before. One of the manifestations of the anti-Republican, though not necessarily monarchist, attitude and the consequence of renaming the state is to change the language used by authorities.

This may be demonstrated by showing the changes in the wording of the proclamation of court judgments. It is known that in many countries-typically in the legal systems of the continental Europe, less so in common law jurisdictions-judgments are proclaimed in a ritual way, with a bound, traditional sentence as a special form of performative utterances, the function of which is to bring the particular judgment into contact to the state, and so to the legal system as a whole. The function of these legal rituals is analyzed from time to time [36: 53-75]. This performative utterance is that judgments are pronounced "in the name of the people", "in the name of the state", "in the name of the law", "in the name of the republic", and the like. Some examples are as follows. In France the République française/Au nom du Peuple français, in Spain the En nombre del Rey, in the Netherlands the Im Naam des Konings, in Germany the In Namen des Volkes, in Italy the In nome der Popolo Italiano, and in Russia the От имени Российской Федерации formulas are used. In those countries where this formula refers to the name of the state, like in Hungary, the wording of them necessarily changes every time when the name of the state (state title) changes.

In Hungary during the twentieth century (some historical details: [45: 34-38]) and at the beginning of this century court judgments were and are pronounced with the following performatives.

\footnotetext{
31 While the Poles have a specific word for the republic (Polish: republika), they call their own republic rzeczpospolita. This word, beyond the fact that it may be used to refer to the Polish-Lithuanian Commonwealth, was originally used to denote the aristocratic national community supplemented with the chosen kingdom, later (in the seventeenth-eighteenth century) the monarchy, while only since the first half of the twentieth century has it been used for the republic.
} 


\begin{aligned} \hline before 1918: & "In the name of His Majesty the King..." \\ in 1918: & "In the name of the Republic of Hungary..." \\ in 1919: & "In the name of the Council Republic..., \\ "In the name of the Hungarian State..." & "In the name of the Hungarian Holy Crown..." \\ between 1920 and 1930: & "In the name of the Republic of Hungary..." \\ between 1930 and 1944: & "In the name of the Hungarian People's Republic.... \\ between 1946 and 1949: & "In the name of the Republic of Hungary..., \\ between 1949 and 1989: & - [no such performative] \\ between 1989 and 2012: & after 2012: \end{aligned}

These utterances were prescribed by different procedural and organizational laws. The last ones (used between 1989 and 2012) [see 60-63] were repealed by the Act CLXI of 2011 [59]. According to its provision court judgments need not refer to the name of the Republic of Hungary or to the State of Hungary. This Act has abolished the old formula but has not introduced a new one. The reasons for that, namely for not introducing a new formula are unknown. The legislator might have supposed in 2011 that the formula "In the name of Hungary!" would be a bit clumsy, that of "In the name of the Hungarian Holy Crown!" would be (still) alienating to many, and that of "In the name of the Hungarian state!" might not have come to anyone's mind. All we can say for sure is that the legislator wanted to cancel the reference for the name of the Republic of Hungary. This means that when judgments are handed down, the courts pronounce them mentioning their own particular name, and they do not have to refer to the state, even they should not mention its name.

\subsection{Name of State and Form of State}

The obvious contradiction between the official justification and actual reasons for changing the name of the Hungarian state in 2011 highlights that the debate on the renaming the state ("name debate") could have easily evolved into a debate on the form of state, ${ }^{32}$ more specifically into a debate on the value of the republic as political form ("republic debate"). It has, however, not evolved into that, in spite of the fact that at the time the Fundamental Law was adopted, many in Hungary feared that the change of the name of the state prepared the ground for a possible future change of the form of state, and despite the other fact that those groups that opposed the political changes of the post-2010 period have focused on republican ideas in their parlance. Fears regarding the restoration of monarchy have proven to be unfounded so far. It is possible to argue that all this happened because changing the form of

\footnotetext{
32 Throughout this paper, the terms form of state or state-form (French: les formes d'Etat, German: die Staatsform) are used to designate the public law structures that reflect and reinforce the most significant elements of political relations, mainly in relation to, and expressed by, the selection, responsibility, and status of the head of state. In this general sense these forms-although they have several classifications and typologies - have been divided into two main categories ("monarchy" and "republic") since the sixteenth century, whatever we may hold about their value in contemporary political science. In English this general meaning of the form of state is also expressed by the term form of government (French forme de gouvernement, German: Regierungsform).
} 
state would have been politically impossible or personally impracticable. In my view, however, it is a misinterpretation of the case.

The analysis of the case shows that contrary to the above assessment and concerning the form of state the main feature of the post-2010 era of Hungary was a significant departure from republican forms in such a way that the primary features of the other main form of state, the monarchy, have not been developed, at least in terms of the formally regulated and outright decision-making procedures, in legally defined competences or in overtly stated structures of responsibilities. This is not to say that decision-making processes and procedures substantially do not remind us of some sort of a monocracy. On the contrary, one of the main characteristics of the state emerged with the Fundamental Law of 2011 and the subsequent transformation of the legal system is that the organization of the government has formally preserved the distinctive forms of a parliamentary republics (prime minister in charge of the parliament, president with representative functions etc.), but substantially it operates in a monocratic manner. The present form of state of Hungary might be located, shapelessly though, somewhere between the monarchy and the republic. It may sound strange, of course, that a form of state is shapeless, but the floating feature of the basic political and public law structures of the state cannot be otherwise described.

Oddly enough, this hovering and floating feature of the basic structure of state corresponds truly, after decades of a historical break, to that of the first major period of the new Hungary of the twentieth century (1920-1944), commonly known as the Horthy era. In that period Hungary had a similarly "shapeless" form of state, termed "monarchy without a king". From a monarchist's point of view, this might have been a doorstep of a republic; from a republican's point of view, if any at that time, it was a doorstep of a monarchy. Analyzing this situation the Austrian public and administrative lawyer, Adolf Merkl, a student of Hans Kelsen, argued in 1925 that the form of state of Hungary was a "clear-cut and genuine republic" and more specifically an "aristocratic republic with royalist features" [48: 34], whereas the constitutional lawyers of Hungary, e.g. Móric Tomcsányi and others, considered it a de jure (but not a de facto) monarchy [53: 301-304]. This mixed nature of de iure and de facto elements of public law was colloquially expressed by the ironic terms of the "royal republic" $[49: 5,7-8]^{33}$ and "a monarchy without a king". The irony is explained by the fact that a "kingdom without a king" was neither a genuine monarchy nor a (genuine) republic, but everyone acted as if it were the first.

Designers of the post-2010 constitutional and political system undertook to build up a new state which is just as mixed and mingled in its de facto working ways, as the interwar version was. Even the "formally maintained republic" with a monocratic decision-making system seems to be analogous to the "formally maintained monarchy" of interwar period with a tint of "aristocratic republic", to use

\footnotetext{
33 The term "royal republic" is not the same as the "crowned republic", coined by Lord Tennyson and applied by James Bryce describing democratic trends in Norway (see [9: vol. 2: 322]), neither the "monarchical republic" used sometimes for qualifying the reign of Queen Elizabeth I or that of Mary I by historians (see [11:31-57, 21: 52]).
} 
Adolf Merkl's term here. The two systems are similar in the preservation of appearances: the first in the preservation of monarchical, the second in the preservation of republican semblances, whereas the first was leaning towards aristocratic style, the second toward monocratic style decision-making. This compound and mingled character or floating feature of the form of the state fits in well with classifications of political regime by contemporary constitutional lawyers as autocracy [25: 36-41, 46: 531-570], a special form of autocracy [35: 545-583] or authoritarian regime [14: 299-302, 38: 1-30, 39: 15, 40: 296-313]. Both are thought of somewhere in the middle of an imaginary scale between democracy and totalitarianism.

This case study has shown that renaming the state was one of the signs of the deployment of a new constitutional system. Changing the name of the institutionalized political community and-as one expert put it-"the ultimate symbol of... [the] statehood", 34 has predicted that a new constitutional and political system would be built in Hungary. It may sound plain hindsight, but it is much more. Since the name change was not without antecedents in the field of the (re-)presentation of the state I claim that changing the name of the state in the Fundamental law 2011 has represented the breakthrough in this continuity. It was a sign whose meaning was understood by few in 2011 because it had many meanings, compressed into a historical one, the return to the appearance of historical continuity. And as historical content unfolded during the last decade, the meaning of this sign became more and more specific.

The immediate antecedents of this situation during the years of constitutional democracy, namely during the years of republic between 1990 and 2010, are also worthy of note. Four important steps could be mentioned here. The first was, as a prelude, the adoption of the coat of arms (escutcheon) of the country, in 1990, in which the representation of the royal crown rests on the traditional shield of a republic. See [55: art 1(2)]. The second was the revitalization and fostering the doctrine about the royal crown, called "Holy Crown doctrine" as a special kind of theory and ideology which — as the opposite of republicanism, highly esteemed during the interwar era-was even provided serious support by legislative declarations. ${ }^{35}$ The third step was bringing the "relic" into life in 2000: the moving of the royal crown from the National Museum to the building of the Parliament and placing it in exactly the same place where the first republic had been proclaimed on 16 November 1918. And finally, the fourth step was the re-dissemination of the doctrine of the so-called historical constitution, hoping that it will come to a new life, will be vitalized, and the ideas behind them will fertilize the new life of the state [51:1-8]. These were all signs that in 1990 the interwar "monarchy without a king" was followed by a republic, established and maintained by no Republicans in the majority, which has been, to say with some exaggeration, a republic without republicans.

\footnotetext{
34 The name of a state is "the ultimate symbol of... [the] statehood", and it is "a crucial element of the self-conception of a state and its population" being able to mobilize "deep feelings" in the population of a state [8: 34].

${ }^{35}$ See e.g. the preamble of Act I of 2000 called the royal crown "Holy Crown" and declared it a "relic", that-quoting the wording of the law-"embodies the continuity and independence of the Hungarian state" [58]. See some details in [30: 17-18].
} 
What is the semiotic lesson of this story, if any, and how could it be summarised? First, if semiotic is a discipline for studying anything which can be used in order to lie (as Umberto Eco has put it succinctly, maybe a little hastily), this case study may show that there are cases where detection of truth or lies of words possible only in historical and sociolinguistic perspective. Second, names are "only words", so tiny things, like breath (as it was stressed during the medieval nominalism-debate), but they are able not only to become part of social reality but to express whole alternative worlds of this reality. Third, this analysis hopefully showed that the renaming of the Hungarian state had an expressive and a constitutional function as well. The first was eliminating republican discourse and weakening republican structures by obscuring the vision of a working republic, the second is the indication of a step towards an authoritarian regime. And although they are not causes of each other, each of them promotes the other, so their co-occurrence and association show that from the one the other could be inferred.

Acknowledgements Open access funding provided by Széchenyi István University (SZE).

Open Access This article is licensed under a Creative Commons Attribution 4.0 International License, which permits use, sharing, adaptation, distribution and reproduction in any medium or format, as long as you give appropriate credit to the original author(s) and the source, provide a link to the Creative Commons licence, and indicate if changes were made. The images or other third party material in this article are included in the article's Creative Commons licence, unless indicated otherwise in a credit line to the material. If material is not included in the article's Creative Commons licence and your intended use is not permitted by statutory regulation or exceeds the permitted use, you will need to obtain permission directly from the copyright holder. To view a copy of this licence, visit http://creativecommons.org/licen ses/by/4.0/.

\section{References}

1. Back, Otto. 1995. Typologie der Ländernamen. Staaten-, Länder, Landschaftsnamen. In Namenforschung/Name Studies/Les noms propres. Ein internationales Handbuch zur Onomastik/An International Handbuch of Onomastics/Manuel international d'onomatique, eds. Ernst Eichler, Gerold Hilty and Heinrich Löffler, 1348-1356. Berlin and New York: Walter de Gruyter, Handbücher zur Sprach- und Kommunikationswissenschaft/Handbook of Linguistic and Communication Science/Manuels de linguistique et des sciences de communication, (2 vols.) in vol. 2.

2. Baer, Helmut David. 2006. The Struggle of Hungarian Lutherans under Communism. Texas: A\&M University Press.

3. Balogh, Zsolt, Balogh-Békési Nóra, et al. 2011 and 2015. The Basic (Fundamental) Law of Hungary. A Commentary of the New Hungarian Constitution, eds. Csink Lóránt, Schanda Balázs and Varga András Zs. ("first" edition); Patyi András, Schanda Balázs and Varga Zs. András ("reprint" edition). Foreword by András Jakab (for "first" edition) and by Péter Paczolay (for the 2015 "reprint" edition). First edition: Dublin: Clarus Press. Reprint (electronical) edition: Budapest, National University of Public Service [NUPS]. http://m.ludita.uni-nke.hu/repozitorium/ bitstream/handle/11410/10136/The\%20Basic\%20Law\%20of\%20Hungary.pdf?sequence=1\&isAll owed $=\mathrm{y}$.

4. Bates, Jennifer Ann. 2004. Hegel's Theory of Imagination. Theory, Study, and Practice. Albany: State University of New York Press.

5. Becher, Johannes R. 1973. Auferstanden aus Ruinen. In: Bechers Gesammelten Werke. Vol. 6.: Gedichte 1949-1958, 61. Berlin, Aufbau, 1973. 
6. Bethlen, Stephen. 1925. Hungary in the New Europe. Foreign Affairs [Publ. by Council on Foreign Relations, USA], 445-458, Vol. 3, No. 3.

7. Brewer-Carías, Allan R. 2010. Dismantling Democracy in Venezuela. The Chávez Authoritarian Experiment. Cambridge: Cambridge University Press.

8. Brunner, Manuel. 2018. Name of a State. In Max Planck Encyclopedia of Comparative Constitutional Law, eds. Rainer Grote, Frauke Lachenmann and Rüdiger Wolfrum. Oxford: Oxford University Press. https://oxcon.ouplaw.com/view/10.1093/law-mpeccol/law-mpeccol-e483.

9. Bryce, James. 1929. Modern Democracies, vol. 12. London: Macmillan.

10. Catañeda, Hector-Neri. 1985. Semantics and Casual Roles of Proper Names. In: Philosophy and Phenomenological Research, 191-113, Vol. 46, No. 1.

11. Collinson, Patrick. 1994. The Monarchical Republic of Queen Elizabeth I. In Elizabethan Essays. London: The Hambledon Press, 31-57.

12. Derrida, Jacques. 1995. Sauf le nom (Post-Scriptum). In On the Name, ed. Jacques Derrida. Stanford: Stanford University Press.

13. Frege, Gottlob. 1892. Über Sinn und Bedeutung. In: Zeitschrift für Philosophie und philosophische, ed. Kritik, Neue Folge, 25-50, Vol. 100.

14. Halmai, Gábor. 2019. Populism, Authoritarianism and Constitutionalism. German Law Journal 20 (3): 296-313.

15. Hegel, Georg Wilhelm Friedrich. 1805/06 (1986). Jenaer Systementwürfe III: Naturphilosophie und Philosophie des Geistes (Jenaer Realphilosophie). Hegels Gesammelte Werke, Vol. 8, Hamburg: Felix Meiner Verlag.

16. Hegel, Georg Wilhelm Friedrich. 1820 (1911). Grundlinien der Philosophie des Rechts. Leipzig, F. Meiner.

17. Helleland, Botolv. 2012. Place Names and Identities. In Names and Identities. Oslo Studies in Language, 4(2), eds. Botolv Helleland, Christian-Emil Ore and Solveig Wikstrøm, 96-117. Oslo: University of Oslo.

18. Hellmann, Manfred W. 1997. Das “kommunistische Kürzel BRD”. Zur Geschichte des öffentlichen Umgangs mit den Bezeichnungen für die beiden deutschen Staaten. In Nominationsforschung im Deutschen, Festschrift für Wolfgang Fleischer zum 75. Geburstag, eds. Irmhild Barz and Marianne Schröder, 93-107. Frankfurt am Main: Lang.

19. Helmbrecht, Johannes, Nishina Yoko, et al. (eds.). 2009. Form and Function in Language Research. Papers in Honor of Christian Lehmann. Berlin, New York: Mouton de Gruyter.

20. Helmbrecht, Johannes. n.d. Form and Function of Proper Names [research paper]. n.d. Academy. edu/Helmbrecht, Johannes.

21. Hunt, Alice. 2009. The Monarchical Republic of Mary I. The Historical Journal 52 (3): 557-572.

22. Ioannidis, Michael. 2010. Naming a State. Disputing over Symbols of Statehood at the Example of "Macedonia". In Max Planck Yearbook of United Nations Law, eds. Armin von Bogdandy and Rüdiger Wolfrum, 507-561. Vol. 14.

23. Jakab, András. 2012. Trianon Peace Treaty (1920). In Max Planck Encyclopedia of Public International Law, ed. Rüdiger Wolfrum, 88-92, Vol. X. Oxford: Oxford University Press. http://www. mpepil.com.

24. Jakobson, Roman. 1985. Critical Question of Linguistic Theory. In Selected Writings. Berlin: Mouton, 1985. vol. VII: Contribution to Comparative Mythology. Studies in Linguistics and Philology, 1972-1982, ed. Stephen Rudy. Berlin: Walter de Gruyter.

25. Kornai János. 2019. The System Paradigm Revisited. Clarification and Additions in the Light of Experiences in the Post-Socialist Region. In: Stubborn Structures. Reconceptualizing Post-Communist Regimes, ed. Magyar Bálint, 21-73. Budapest and New York, CEU Press.

26. Küpper, Herbert. 2010. Ungarn: Grundlagen des Verwaltungsrechts. In: Handbuch Ius Publicum Europaeum, eds. Armin von Bogdandy, Sabino Cassese, Peter M Huber, 399-444. Bd. 3: Verwaltungsrecht in Europa: Grundlagen. Heidelberg: C. F. Müller.

27. Lipset, Seymour Martin. 1979. The First New Nation. The United States in Historical and Comparative Perspective. New Brunswick: Transaction.

28. Marcuse, Herbert. 1964 (2012). One-Dimensional Man. Studies in the Ideology of Advanced Industrial Society. Boston: Beacon Press.

29. Morrison, Kenneth. 2008. Montenegro. A Modern History. London: I. B.Tauris.

30. Péter, László. 2012. The Holy Crown of Hungary, Visible and Invisible. In Hungary's Long Nineteenth Century. Constitutional and Democratic Traditions in a European Perspective. Collected Studies, ed. Lojkó Miklós, 15-112. Leiden and Boston: Brill. 
31. Plato.1998. Cratylus. Transl. C.D.C. Reeve. Cambridge (Ind.): Hackett Publishing Co.

32. Renner, Karl. 1994. Außenpolitische Dokumente des Republik Österreich 1918-1938. Band 2: Im Schatten von Saint Germain, eds. Klaus Koch, Walter Rauscher, Arnold Suppan. Wien, München: Verlag für Geschichte und Politik.

33. Salzborn, Samuel. 2015. Schleichende Transformation zur Diktatur. Ungarns Abschied von der Demokratie. In Kritische Justiz. Vierteljahresschrift für Recht und Politik, 71-82, Vol. 48 (Heft 1).

34. Schanda Balázs. 2011 and 2015. Constituent and Constitutional Entities. In The Basic (Fundamental) Law of Hungary, 57-61. See at Balogh et al.

35. Scheppele, Kim Lane. 2018. Autocratic Legalism. In University of Chicago Law Review, 545-583, Vol. 85.

36. Stolleis, Michael. 2009. In the Name of the Law. In The Eye of the Law. Two Essays on Legal History by Michael Stolleis. Transl. Thomas Dunlap. Abingdon: Birkbeck Law Press.

37. Takács, Péter. 2019. On Stateform of Hungary between 1920 and 1944: Applicability of the Term "Monarchy without a King". In: Journal on European History of Law, 139-148, Vol. 10, No. 2.

38. Tóth, Gábor Attila. 2017. Authoritarianism. In Max Planck Encyclopedia of Comparative Constitutional Law, eds. Rainer Grote, Frauke Lachenmann, Rüdiger Wolfrum. Oxford: Oxford University Press. https://oxcon.ouplaw.com.

39. Tóth, Gábor Attila. 2019. Constitutional Markers of Authoritarianism. Hague Journal on The Rule of Law 11 (1): 37-61.

40. Tóth, Gábor Attila. 2013. Historicism or Art Nouveau in Constitutional Interpretation? German Law Journal 14: 1615-1626.

41. Voltaire [François-Marie Arouet]. 1756. Essai sur les moeurs et l'esprit des nations, et sur les principaux faits de l'historie, depuis Charlemagne jusqu'a Louis XIII. Esp.: Chapter 70: De l'empereur Charles IV. [In Euvres complètes de Voltaire. Vol. 7]. Paris, Hachette, 1859.

42. Xenakis, Jason. 1956. Function and Meaning of Names. Theoria 22 (1): 49-60.

\section{References in Hungarian language}

43. Ablonczy, Bálint. 2011. Az alkotmány nyomában. Beszélgetések Szájer Józseffel és Gulyás Gergellyel [Conversations on the Fundamental Law of Hungary. Interviews with József Szájer and Gergely Gulyás]. Budapest: Elektromédia.

44. Bańczerowski, Janusz, Bárdosi Vilmos. 2004. A "haza” fogalma a világ magyar nyelvi képében [The concept of "motherland" in the Hungarian linguistic image of the world]. In Magyar Nyelvôr. No. 128. 1-10. (2004).

45. Kajtár, István, Kengyel Miklós. 1982. “A Népköztársaság nevében!” Adalékok az ítéleti preambulumhoz ["In the name of the People's Republic!" Additions to the preamble of court judgments]. In Jogtudományi Közlöny. Vol. [new series] 37. 34-38.

46. Kis, János. 2019. Demokráciából autokráciába [From Democracy to Autocracy]. In Alkotmányos demokrácia. Régebbi és újabb közelítések [Constitutional Democracy. Older and Newer Approaches]. Budapest: Kalligram, 531-570.

47. Küpper, Herbert. 2014. Magyarország átalakuló közigazgatási bíráskodása [The transforming administrative adjudication of Hungary]. In MTA Law Working Papers. No. 59 1-29.

48. Merkl, Adolf. 1925. A mai Magyarország államformájának kérdéséhez [On the Issue of the Form of State of Today's Hungary”]. In Jogtudományi Közlöny, 33-35, Vol. [new series] 60, No. 5.

49. Schweitzer, Gábor. 2017. A magyar királyi köztársaságtól a Magyar Köztársaságig [From the Hungarian Royal Republic to the Republic of Hungary]. Pécs: Publikon.

50. Schweitzer, Gábor. 2018. Állami és nemzeti jelképek [State Symbols and National Symbols]. In Alkotmányjog [Constitutional Law], ed. Halász Iván, 211-218. Dialóg Campus: Budapest.

51. Szente, Zoltán. 2019. A 2011. évi Alaptörvény és a történeti alkotmány összekapcsolásának mítosza [The myth of linking the Fundamental Law of 2011 with the historical constitution]. In Közjogi Szemle, 1-8, Vol 12, no. 1 .

52. Takács, Albert et al. 2016 and 2018. Alkotmány-Államtan. Kormányzati tanulmányok [Constitution-Theory of State. Studies on Government]. Budapest: NKE VTI (first and second edition).

53. Tomcsányi, Móric. 1940. Magyarország közjoga [Public law of Hungary]. Budapest: Királyi Magyar Egyetemi Nyomda, 3rd edn. 


\section{Constitutions and legislation}

54. Constitution of Japan, 3 May 1947.

55. Constitution of the Republic of Hungary: Act XXXI of 1989 on the Constitution of the Republic of Hungary, originally passed as Act XX of 1949 and amended on several occasions.

56. Fundamental Law of Hungary, 25 April 2011. Official English translation is available at http://www. kormany.hu/download/f/3e/61000/TheFundamentalLawofHungary_20180629_FIN.pdf.

57. Act XLIV of 1990 (3 July 1990) amending the Constitution of the Republic of Hungary on the Coat of Arms of the Republic of Hungary.

58. Act I of 2000 (1 January 2000) on the Commemoration the Establishment of thy State by St Stepen and on the Holy Crown.

59. Act CCI of 2011 (23 December 2011) on the amendment of particular Laws in connection with the Fundamental Law.

60. Act CLXI of 2011 on the Organization and Administration of Courts (in effect since 2012).

61. Act LXVI of 1997 on the Organization and Administration of Courts.

62. Act XIX of 1998 on Criminal Procedure.

63. Act III 1952, on the Code of Civil Procedure as amended in 1972, 1984, and by the Act CX of 1999.

64. Governmental Decree of Hungary, No. 322/2011 issued on 27 December 2011.

65. Magyarország Alaptörvénye. Indokolás (in Hungarian) [Official explanatory note accompanying the bill submitted by the drafters]. Budapest: Országgyúlés Hivatala [Office of Parliament]. Document number: T/2627. 14 March 2011. https://www.parlament.hu/irom39/02627/02627.pdf.

\section{Political journalism}

66. Ehrenparade der NVA [Nationale Volksarmee] zum Nationalfeiertag (in German) [Parade of the People's Army on the National Holiday]. In Neues Deutschland. 7. October 1986.

67. Orbán: Számunkra a köztársaság egy üres szó, az csak egy ruha (in Hungarian) [Orban: For us, republic is an empty word, it's just a dress]. In $m a . h u$ [electronic newspaper] based on the news of MTI, the Hungarian News Agency, 14 March 2006. (electronically available at http://www.ma.hu/ $\operatorname{tar} / \mathrm{rcikk} / \mathrm{a} / 0 / 143121 / 1)$

68. News release by MTI, the Hungarian News Agency, 24 April 2019.

Publisher's Note Springer Nature remains neutral with regard to jurisdictional claims in published maps and institutional affiliations. 